\section{Agricultural Education}

The Minister of Agriculture and Fisheries, after consultation with the Minister of Education, has set up a 'working party' with the following terms of reference: "To review the relations between the agricultural education service of Local Authorities and the National Agricultural Advisory Service, and to make proposals for their more effective cooperation; to examine the need for an inspectorate of agricultural education ; and to consider the future of the Joint Advisory Committee on Agricultural Education".

The mombership of the 'working party' is as follows : Lord Carrington, Joint Parliamentary Secretary to the Ministry of Agriculture and Fisheries (Chairman); F. Bray, under-secretary in the Ministry of Education; E. Shaw Browne, chairman of the Nottinghamshire Agricultural Executive Committee; W. S. Gibson, provincial director, National Agricultural Advisory Service; Dr. T. Loveday, chairman of the Joint Advisory Committee on Agricultural Education ; J. H. Parker Oxspring, director of education, Staffordshire; Prof. R. Alun Roberts, University College of North Wales, Bangor; F. Rollinson, recently of the National Union of Agricultural Workers ; Sir James Scott-Watson, chief scientific adviser to the Ministry of Agriculture and Fisheries; W. J. Simmons, farmer ; Sir Offley Wakeman, chairman of the Shropshire Education Committee ; C. H. M. Wilcox, undersecretary in tho Ministry of Agriculture and Fisheries. All communications should be sent to Mr. H. F. Greenfield, at the Ministry of Agriculture and Fisheries, 1-4 Cambridge Terrace, Regent's Park, London, N.W.1.

\section{Science in Communist States}

THE Society for Freedom in Science has recently published Occasional Pamphlet No. 13, under the title "Science in a Satellite State of the Soviet Union" (pp. 16 ; from the Department of Zoology, University Museum, Oxford; $1 s .3 d$.), which is a summary, without comment, of speeches made at the "Ideological Conference of University Scientific Workers", held at Brno, Czechoslovakia, during February 27March 1, 1952, the material being taken from bulletins of the Czechoslovak News Agency. No more dignified way could have been adopted of correcting the impression sometimes held that in Communist States the man of science is free to pursue the search for truth wherever it may lead him. The speeches summarized in the pamphlet show clearly the domination and direction of science by political ideologies in such countries, how secondary can be the loyalty of the scientific worker to his own discipline, and the way his thinking is required to be subservient to the doctrines and needs of the State.

\section{Royal Society: Officers and Council}

THE following have been elected Officers and Council of the Royal Society for the ensuing year : President : Dr. E. D. Adrian; Treasurer and Vice-President: Sir Thomas Merton; Secretaries and Vice-Presidents : Sir Edward Salisbury and Sir David Brunt ; Foreign Secretary: Sir Cyril Hinshelwood; Other Members of Council: Prof. P. A. Buxton, Mr. H. Constant, Prof. P. I. Dee, Prof. E. C. Dodds, Prof. H. J. Emeléus, Sir Howard Florey (vice-president), Prof. D. R. Hartree, Prof. E. G. T. Liddell, Prof. E. T. Maskell, Prof. R. A. McCance, Prof. H. H. Plaskett, Prof. W. J. Pugh, Prof. Alexander Robertson, Dr. R. Stoneley, Prof. G. Temple, Prof. C. M. Yonge.

\section{Announcements}

Prof. Arthur Holmes, regius professor of geology in the University of Edinburgh, has boen elected a corresponding member of the (teological Society of Stockholm.

Prof. R. J. W. LeFìvre, professor of chemistry in the University of Sydney, has been awarded the H. G. Smith Memorial Medal by the Royal Australian Chemical Institute, in recognition of his contributions to physical organic chemistry over the past ten years.

Dr. T. H. C. TaYlor has been appointed as from April 1953 to the recently ereated post of deputy director, in the senior principal scientific officer grade of the Scientific Civil Service, at the Anti-Locust Research Centre, London. Dr. Taylor is at present assistant director of the Commonwealth Institute of Entomology, which he joined in 1944, after long and distinguished service in Fiji and Uganda, mainly connected with research on the ecological and biological control of insects.

Mr. M. W. Perrin, at present research adviser to Imperial Chemical Industries, Ltd., has been appointed chairman of the Wellcome Foundation. Ltd., in succession to Mr. H. E. Sier, who is retiring at the end of January. Before the Second Wor'd War Mr. Perrin was a member of the Research Department of the Alkali Division, and also of the Headquarters Research Department of Imperial Chemical Industries, Ltd. During the War he was assistant director of Tube Alloys (the war-time atomic energy organization), and from 1946 until 1951 was deputy controller (technical policy) in the Division of Atomic Energy of the Ministry of Supply.

IN order to encourage the writing of papers at a standard suitable for assimilation by a non-specialist reader having some general scientific knowledge, the publishers of the scientific journal Research are organizing an essay competition, with prizes of $£ 100$, $£ 50$ and possibly others as well, for which entries may be made by persons actively engaged on research work. Such essays should be about three thousand words in length and should deal with any recent scientific investigation (not necassarily the writer's own work) and its potential application to industry. Entries, which will bo judged by a committee to be appointed by the Scientific Advisory Board of Research, should reach the offices of Research, 4-6 Bell Yard, London, W.C.2, on or before April 30, 1953.

THE Institution of Naval Architects is offering during 1953 the following scholarships to British subjects (age limit shown in brackets), which, except where otherwise stated, must be applied for before May 30, 1953: Institution scholarship in naval architecture (23), for apprentices or pupils in the Royal dockyards or private shipyard (entries before Tanuary 15); Trewent scholarship in naval architecture (20), for apprentices or pupils in private shipyards ; Denny scholarship in naval architecture and one in marine engineering (19), tenable for four years in the University of Glasgow, with apprenticeship of five years; Parsons scholarship in marine engineering $(21)$, for apprentices or pupils in marine engine works or the Royal dockyards. Further particulars can be obtained from the secretary of the Institution at 10 Upper Belgrave Street, London, S.W.1. 